\title{
Big Data Spatial Geographic Information System (GIS) on Mapping Distribution Point Shelter Garbage
}

\author{
Ahmad Ihsan*, Khairul Muttaqin, Rizalul Akram, Nurul Fadillah \\ Faculty of Engineering \\ Samudra University \\ Langsa, Indonesia \\ *ahmadihsan@unsam.ac.id
}

\begin{abstract}
Garbage is a problem that continues to grapple in people's lives, especially in urban areas. Therefore, good waste management is needed. To manage waste, of course, people need correct, accurate and timely information regarding the implementation of waste management. To find out the location of the waste, a geographic information system (GIS) was built which is useful for displaying the distribution of TPS location data as information to the public and officers, as well as a means of reporting for the public regarding waste problems. The system was built using CodeIgniter and ArcGIS, which are a framework and javascript library for digital map purposes such as markers and clusters. The result of this research is a geographic information system mapping the location of the waste disposal locations in Langsa City as a digital mapping visualization of the waste TPS locations. Public reporting facility to report waste location points so that the coordinates and location of garbage piles can help related parties in making decisions and actions that are more targeted in overcoming waste location problems and also monitoring the presence of waste. This system is expected to be useful for the community and related agencies to be able to work together and interact with technology to better solve the waste problem.
\end{abstract}

Keywords-waste management, distribution of TPS location, public reporting facility

\section{INTRODUCTION}

The development of residential areas and the increasing population have caused several problems, including the capacity of the Garbage Collections Places (TPS) which exceeds the capacity. Conditions like this can cause environmental pollution so that it becomes a source of disease because of the large amount of garbage that has accumulated which exceeds the capacity $[1,2]$. Garbage Collections (TPS) which are managed by the Department of Environment, Cleanliness and Landscaping of Langsa City are divided into two types, namely, Temporary Shelters (TPS) and Final Processing Sites (TPA). its existence is still not clear to the public. This is proven by the existence of Illegal Garbage Collections which can damage the cleanliness of the environment. So that it is necessary to map the distribution of the fulfillment of the facilities for cleaning the garbage collection places (TPS) which is managed by the Environment, Cleanliness and Gardening Service of Langsa City so that it can be known by all Langsa City people [3]

With the development of the world of information nowadays it makes a lot of convenience, one of the technologies that are currently being developed is the Geographic Information System (GIS). The information system regarding the mapping of the distribution of waste storage places (TPS) is a combination of GIS technology and the web that allows information to be visualized on the web so that it can be accessed by the wider community, especially the people of Langsa City without any time and place limits. Most of the data to be handled in GIS is spatial data, which is geographically oriented data, has a certain coordinate system as its reference base and has two important parts that make it different from other data, namely location information (spatial) and descriptive information (attribute) [4].

This system was built using Arcgis to display a map of garbage collection places (TPS) locations in Langsa City. TPS spatial data were obtained through the Department of Environment, Cleanliness and Landscaping of Langsa City as well as a survey of the location of direct garbage collection sites. The Geographical Information System for the Mapping of Waste Storage Sites consists of 3 types, namely the Final Processing Site Marker (TPA), Temporary Shelters (TPS) and proposed new TPS by the community. The results of this study are expected to provide detailed and accurate information about the mapping of the distribution of waste storage, both temporary shelters, final processing sites and proposals for new waste storage by the community as well as increasing public awareness of a clean and healthy environment [5].

\section{RESEARCH METHODS}

The flow of the mapping system for the distribution of waste storage areas is as follows: 


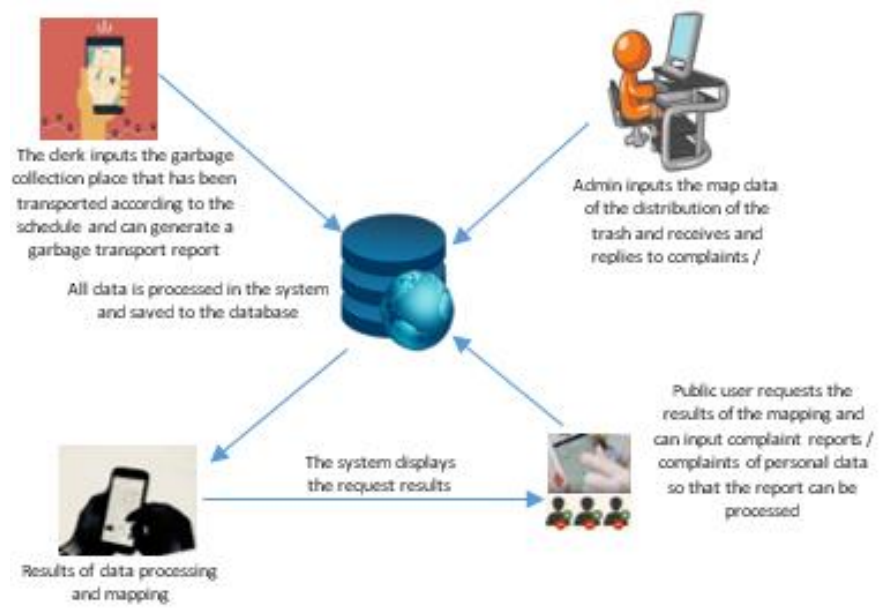

Fig. 1. The flow of mapping system for the distribution of waste storage areas.

From figure 1, it can be explained that:

- The admin can $\log$ in as an administrator using a username and password and is in charge of accommodating all master data, namely managing the vision and mission, organizational structure, managing data on the landfill, mapping it by inputting markers which are symbols of a garbage shelter according to latitude and longitude by determining in certain subdistricts and sub-districts, receive and reply to community reports. The data that has been inputted will automatically be updated on the system.

- Officers can log in as an officer using a username and password who will be in charge of answering and responding to requests that come in from the public and immediately acted upon by the officer.

- The general public can see and access a website where there is a mapping of waste storage areas and information. The community can also choose the location of the mapped garbage collection area to report complaints of problems or point the location of the rubbish point to complaints about the emergence of illegal garbage storage places that are troubling residents.

- The system will display the first layer according to the request from the user. The system displays the mapping and base map which can be selected by the user. Users can search for the trash they are looking for in the search. The mapping also displays clustering so that the distribution of the trash cans is not seen piling up

The architecture of the mapping system for the distribution of garbage dumps can be seen in figure 2 :

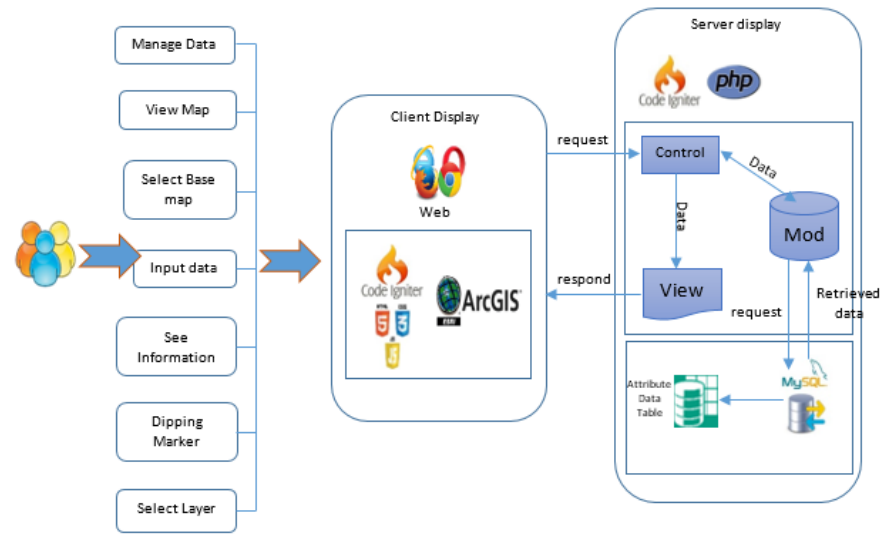

Fig. 2. The architecture of mapping system for distribution of garbage dumps.

The description of the architecture in the image above is as follows:

- Each user will send a request according to their respective request for access rights to the client.

- Client view is an application that communicates with the server as a data provider via web protocols such as Hyper Text Transfer Protocol (HTTP) developed with a web browser (Mozzila Firefox, Chrome, Opera, Internet Explorer, etc.)

- The request will be forwarded to the server view which will connect to the spatial database and process requests from each user and send the request to the database server using the PHP programming language with the CodeIgniter framework which has three components, namely model, view and controller. User requests and data will be accepted by the controller to determine what the system will process. Furthermore, the controller will connect requests from users to the part of the model that is directly related to the database to manipulate data such as viewing data, entering data, updating data, deleting data, and others. After the request is successfully executed, the view will provide a display response to the user.

- CodeIgniter on the client side acts to produce a dynamic website appearance

- Map data that is processed using ArcGIS is received by the application which displays the data according to the map layer being processed.

\section{RESULTS AND DISCUSSION}

Distribution of Temporary Garbage Collectors and Final Processing Places in Langsa City Area. See figure 3 below. 


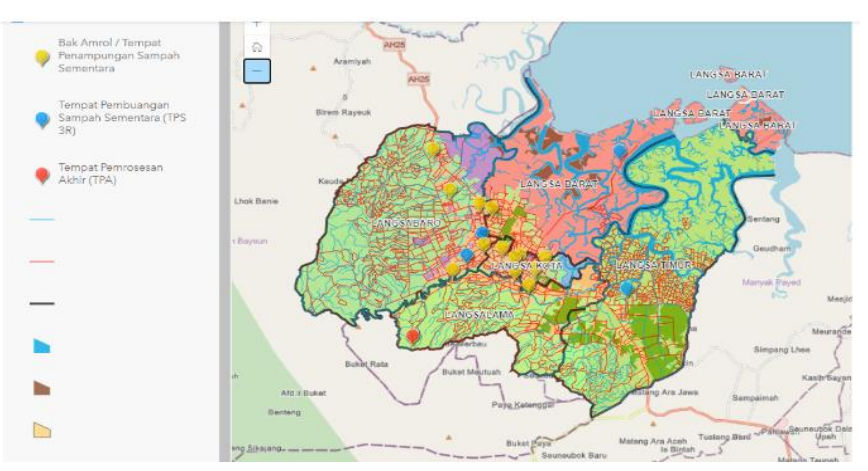

Fig. 3. Mapping of the distribution of garbage dumps in Langsa City.

Based on the results of research through data collection and field surveys, there are 13 points for temporary waste storage (amrol tub), 4 points for temporary 3R waste storage, and 1 point for final processing (TPA) spread across five sub-districts in Langsa City, namely Langsa Lama District (TPS3R: 0, TPS / Bak Amrol: 3, TPA: 1), Langsa Baro District (TPS3R: 2, TPS / Bak Amrol: 4, TPA: 0) Langsa Kota District, West Langsa District and East Langsa District. The distribution of garbage dumps in the Langsa City area can be illustrated in the following distribution graph.

Details of the distribution of garbage dumps that are scattered in the Langsa city area can be seen in the following figure 4 and table 1 :

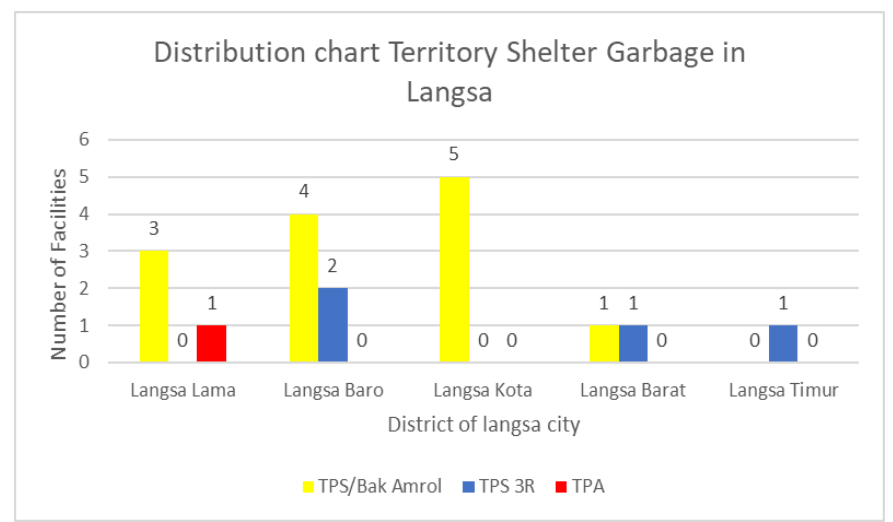

Fig. 4. Graph of TPS distribution in Langsa City area.

Details of the distribution of garbage dumps that are scattered in the Langsa city area can be seen in the following table.
TABLE I. DATA DISTRIBUTION REGION SHELTERS GARBAGE IN LANGSA

\begin{tabular}{|c|c|c|c|c|}
\hline No & Type & Location & $\begin{array}{c}\text { source of } \\
\text { funds }\end{array}$ & Capacity \\
\hline 1. & TPS 3R & $\begin{array}{l}\text { Kuala langsa } \\
\text { Langsa Timur } \\
\text { Lorong Utama } \\
\text { Geudubang Jawa }\end{array}$ & $\begin{array}{l}\text {-DLH } \\
\text {-DLH } \\
\text {-Gampong } \\
\text {-Gampong }\end{array}$ & $\begin{array}{l}4,64 \\
\mathrm{~m} 3 / \text { hari }\end{array}$ \\
\hline 2 & $\begin{array}{l}\text { Bak } \\
\text { Amrol/TPS }\end{array}$ & $\begin{array}{l}\text { Alur dua } \\
\text { Perumnas } \\
\text { Lr.Pendidikan } \\
\text { Jl. Rel Kereta Api } \\
\text { Meurandeh } \\
\text { Sidoerjo } \\
\text { Gp.Tengoh } \\
\text { Gp. Melayu } \\
\text { Gp. Alue Berawe } \\
\text { RSUD } \\
\text { Payabujuk Tunong } \\
\text { Blang Pase } \\
\text { Payabujuk Bromo }\end{array}$ & $\begin{array}{l}\text {-Gampong } \\
\text {-Gampong } \\
\text {-DLH } \\
\text {-Gampong } \\
\text {-Gampong } \\
\text {-Gampong } \\
\text {-Gampong } \\
\text {-Gampong } \\
\text {-DLH } \\
\text {-Gampong } \\
\text {-Gampong } \\
\text {-Gampong }\end{array}$ & $6 \mathrm{~m} 3 /$ hari \\
\hline 3 & TPA & Gp. Pondok kemuning & -DLH & \\
\hline
\end{tabular}

Submission of location information in the mapping system of the distribution of the garbage collection sites is very interactive, where the user only selects one of the location markers on the map, and then the system will display detailed information in the form of a pop up system. The following is a display of the location selection process accompanied by details of the location using the pop up system. See figure 5 below.

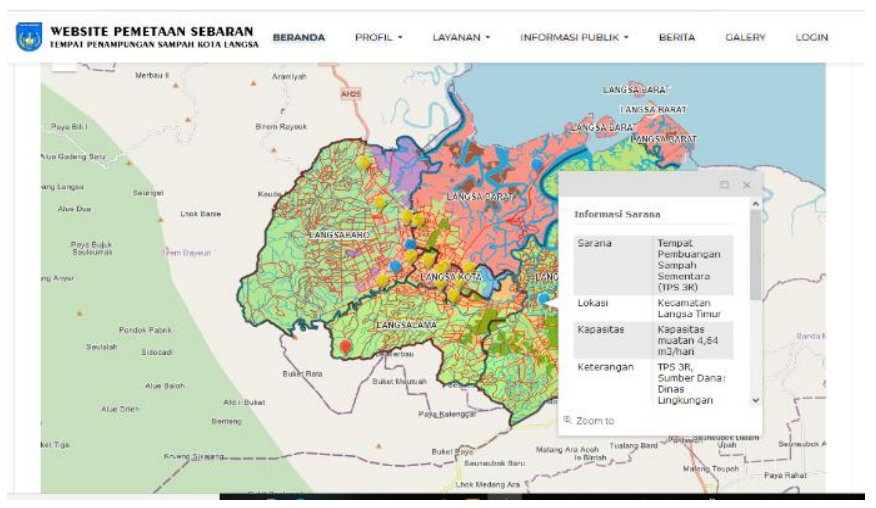

Fig. 5. WebGIS display distribution mapping garbage collection bin with a pop up system feature.

In the application of Big Data Spatial Geographic Information System (GIS) in the Mapping of the Distribution of Garbage TPS (TPS), it produces several spatial big data as supporting data for mapping, such as administrative data for the sub-district area, main road data, residential roads, rivers, river flows, fields, rice fields and settlements. See figure 6 below. 


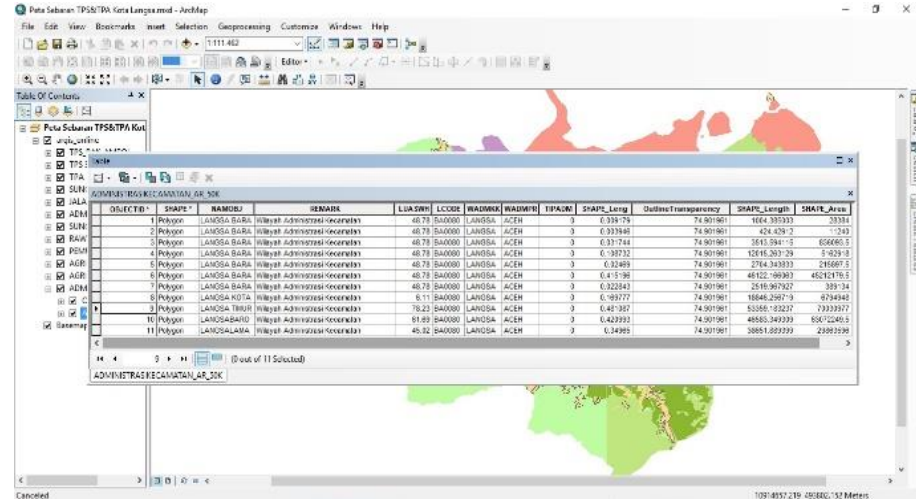

Fig. 6. Spatial data attributes for Langsa City complaints and requests for new waste shelter by the community.

In the application of the Big Data Spatial Geographic Information System (GIS) in the Mapping of the Distribution of Garbage Dumpsites, there are services to the public regarding complaints and requests for new waste storage places in the Langsa City Area. This service aims to facilitate the community regarding access to garbage storage areas and to improve services for waste management, in this case the Langsa City Environmental Service.

This service for complaints and requests for the New Garbage Shelter by the community is an additional feature contained in the application of the WebGis. Mapping the distribution of garbage dumps in Langsa City. To access the complaint page and request for a new trash can, the user is asked to $\log$ in first, if he doesn't have an account, he can register an account on the register page, then submit, then the user will get an email reply to confirm the login account. The following figure 7 shows login system.

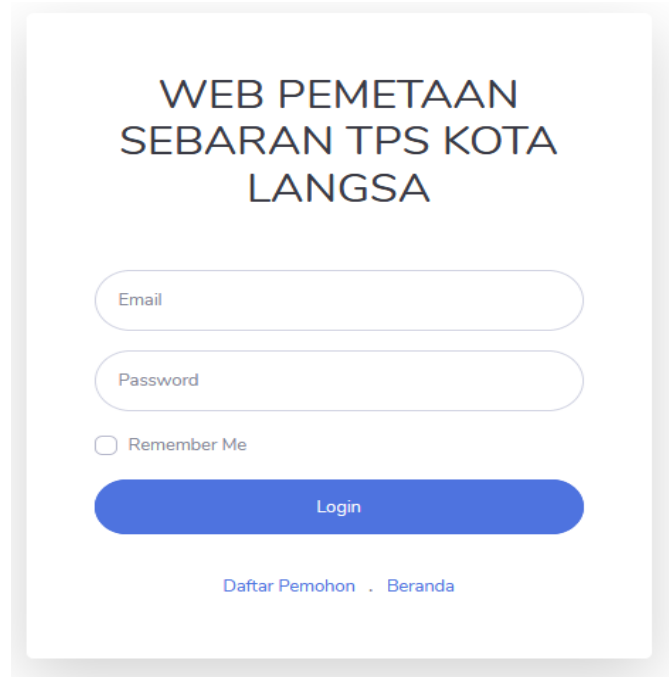

Fig. 7. User login page on complaints and new application for garbage collection service.

After completing the login process, the user will then be presented with a complaint page display. In this complaint page the user is asked to choose the type of service he wants to use first. There are only two services that can be chosen, namely the complaint service and the service for requesting a new waste collection place. Next, fill in the form with the correct information and data. The following is a display of the process for filling out the complaint service form and requesting a new waste collection place.

After the process is complete, the user can see the reporting status, whether it is waiting, processing, rejected or the report is received. If the user is satisfied and the report results are as expected, the user can complete the complaint or report. See figure 8 below.

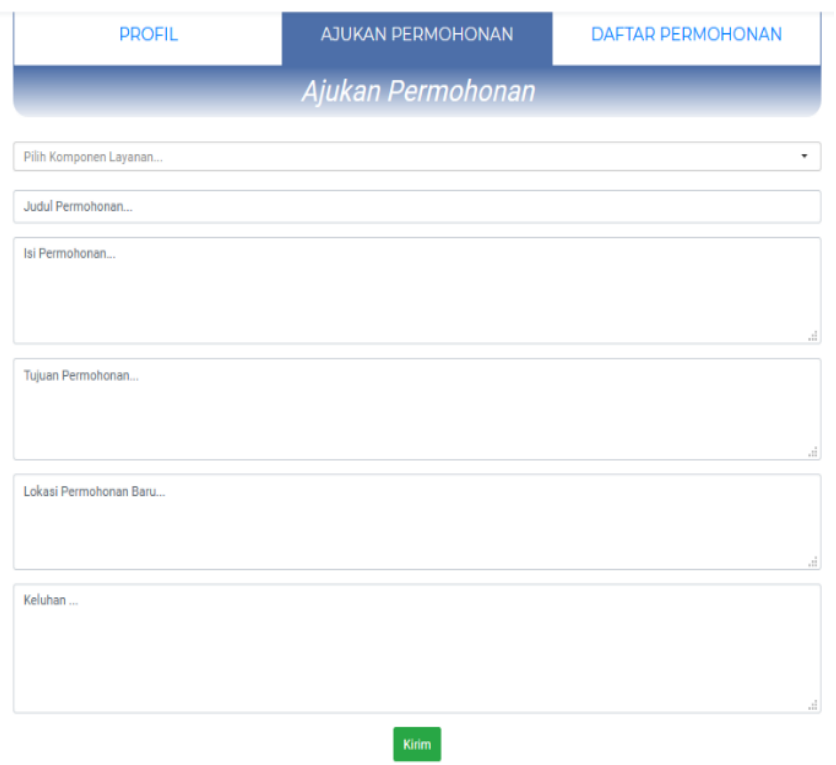

Fig. 8. User request page on complaints and new application for garbage collection place.

With the results of the application of the Big Data Spatial Geographic Information System (GIS) on the Mapping of the Distribution of Garbage Tins and the service features for complaints and requests for new trash containers by the community, it is hoped that it can make it easier for the public to find out information on the location of the distribution of garbage dumps in the Langsa City Region and raise awareness. community related to waste management that spreads to community settlements. So that the waste problem in the Langsa City Area can be resolved properly in order to create a clean and waste-free Langsa City.

\section{CONCLUSION}

Based on the descriptions that have been discussed, the conclusions that can be drawn are mapping of the distribution of landfills can be done by utilizing a Geographical Information System (GIS) which facilitates the maintenance of TPS data and makes it easier for users to find locations and information on cleaning facilities through the distribution of TPS and their information. The existence of community reports in this GIS can be used by the community to report illegal or problematic waste points which can help the Environmental 
Service in making decisions, follow up on the distribution of trash bins and observe and evaluate with the help of visual displays through the GIS web mapping of locations garbage disposal point.

\section{REFERENCES}

[1] Sunardi, R. Soelistijadi, and D.U. Handayani, "Pemanfaatan Analisis Spasial untuk Pengolahan Data Spasial Sistem Informasi Geografi," J. Teknol. Inf. Din., vol. X, no. 2, pp. 108-116, 2005.
[2] J.M. Kapetsky and J. Aguilar-Manjarrez, "Geographic information systems, remote sensing and mapping for the development and management of marine aquaculture," no. April. 2007.

[3] A. Mizwar, P. Studi, T. Lingkungan, F. Teknik, U. Lambung, and T. K. Banjarbaru, "Pemilihan Lokasi Tempat Pengolahan Akhir (Tpa) Sampah Kota Banjarbaru Menggunakan Sistem Informasi Geografis ( Sig )," vol. 8, pp. 1-7, 2010.

[4] A. Mizwar and P.R. Kartini, “2. Aplikasi Sistem Informasi Geografis (Sig) Untuk Pemetaan Sebaran Tempat Pembuangan Sampah Ilegal Di Kota Banjarbaru, Kalimantan Selatan,” Jukung (Jurnal Tek. Lingkungan), vol. 2, no. 1, pp. 13-24, 2016.

[5] A. Ardiansyah and K. Kardono, "Sistem Informasi Geografis (Sig) Pemetaan Jaringan Pipa Dan Titik Properti Pelanggan Di Pt Aetra Air Tangerang," J. Ilm. FIFO, vol. 9, no. 1, p. 81, 2017. 